\title{
MEASURING HEALTHCARE QUALITY - PARADIGM OF MEDQUAL
}

\author{
Ksenija Musa-Juroš ${ }^{1}$, Josipa Mijoč², Jasna Horvat ${ }^{2}$, Vesna Ilakovac ${ }^{3}$, \\ Suzana Marković ${ }^{4}$ and Aleksandar Racz ${ }^{5}$
}

${ }^{1}$ Department of Surgery, Osijek University Hospital Center, Osijek, Croatia;

${ }^{2}$ Department of Quantitative Economics and Informatics, Osijek Faculty of Economics, Osijek, Croatia;

${ }^{3}$ Department of Medical Statistics, Osijek Faculty of Medicine, Osijek, Croatia;

${ }^{4}$ Department of Quantitative Economics, Faculty of Tourism and Hospitality Management, University of Rijeka, Opatija, Croatia; ${ }^{5}$ University of Applied Health Sciences, Zagreb, Croatia

SUMMARY - Medical activity is assumed to be service activity the effects of which can be measured. The SERVQUAL scale was used as a starting point for our research, which resulted in a new, adopted scale called MEDQUAL. The MEDQUAL scale aims to measure the quality of healthcare provided by medical staff of one hospital department instead of the overall quality of hospital services or parts of services on which medical staff in one department has no influence. The study was conducted in a clinical hospital department in Croatia and included 300 respondents (169 patients and 131 medical staff members). The MEDQUAL scale, designed and tested in the study, showed high reliability in all established dimensions, i.e. trust in doctors (Cronbach's Alpha 0.923), nursing professionalism (0.913), medical professionalism (0.938), and departmental organization (0.810). The scale proposed evaluates both patient satisfaction with the quality of healthcare received and medical staff satisfaction with the quality of healthcare provided. The results were comparable to the groups of respondents, departments, and institutions with potential longitudinal studies of this phenomenon. MEDQUAL is a simple, repeatable and cost-effective scale, applicable to almost all departments and used for measuring the quality of healthcare services both provided and received, the aim of which is to contribute to the assessment of healthcare quality and its improvement.

Key words: Quality of Health Care; Medical Staff; Hospital Departments; Croatia; Patient Satisfaction; Surveys and Questionnaires; Longitudinal Studies; Quality Indicators, Health Care

\section{Introduction}

Development of the service sector and its leading role in relation to other types of activities in terms of the number of employees and service users at the end of the $20^{\text {th }}$ century caused development of methods for measuring the level of quality of the services provid$\mathrm{ed}^{1-3}$. This trend has also spread to medicine as a result of an increase in patient expectations, which have ulti-

Correspondence to: Ksenija Musa-Juroš, MD, Department of Surgery, Osijek University Hospital Center, Josipa Huttlera 4, HR-31000 Osijek, Croatia

E-mail: ksenija.musa1@gmail.com

Received June 30, 2017, accepted May 11, 2018 mately led to the development of private practice, as well as a growing need for assessing economic impacts of medical activities in terms of cost-effectiveness. There has been a significant number of studies measuring healthcare quality that are primarily based on Parasuraman's SERVQUAL or its minimum adaptation $^{3-23}$. Most studies essentially contain some elements of healthcare services which cannot be influenced by medical staff because these are either inherited problems (e.g., urban plan, parking, size of hospital rooms, access to sanitary facilities, etc.) or within the domain of other hospital departments (e.g., meal delivery services, bed linen cleaning and delivery services, etc.). This indicates the need to develop a scale 
that would measure the quality of specific healthcare services provided by medical staff in a department instead of the quality of healthcare services in general. The authors tested and proposed the MEDQUAL scale that simultaneously assesses the quality of healthcare provided by medical staff and received by patients in one hospital department. In addition, opinions and ratings of both patients and medical staff referring to the medical service provided or received were analyzed. Both patients and medical staff were asked to rate the trust in doctors, medical professionalism, nursing professionalism, and organization of the department.

\section{Methods}

\section{Research setting and sample}

The study was conducted at a surgical department in a university hospital in Croatia that covers all surgical specialties (abdominal, trauma, vascular, plastic, cardiac, thoracic and pediatric surgery with emergency and follow-up outpatient care). The department under study has 200 beds and performs approximately 13,000 surgical operations and minor surgery procedures annually and approximately 90,000 examinations through emergencies and follow-ups, as well as examinations in other departments and clinics. Before the study, both approval from the institutional Ethics Committee and Josip Juraj Strossmayer University of Osijek and consent for participation were obtained from medical and nursing staff working at the surgical department and from the patients.

\section{Sample size requirements}

Factor analysis was used for testing the constructs and the measurement scale. The study included 300 respondents and met the criterion referring to the sample size of 100 and more respondents (the ratio of $10: 1$, or 10 respondents for each variable included in factor analysis) since 25 variables of the proposed scale were tested ${ }^{24,25}$.

\section{Data collection}

A structured questionnaire consisting of two parts was developed for the purpose of this study. The first part contained MEDQUAL scale items, while the second part examined socio-demographic characteris- tics of respondents. The study involved all doctors from the department under study $(n=30)$. The number of participants in the groups of nursing staff and patients was determined proportionally to the ratio between the number of beds and the size of the department. The sample was created by combining a convenience and quota sample. The convenience sample consisted of respondents associated exclusively with the department under study, while the quota sample referring to the quota of medical staff was created based on the ratio (i.e. quota) of the number of medical staff working at the department under study and the number of medical staff employed.

\section{Research instrument}

The construct was designed by modifying the SERVQUAL scale. An expert committee consisting of five members (psychiatrist, economist, statistician/ methodologist, surgeon, and lawyer) identified measurable elements of quality associated with the department under study. The items and dimensions of the MEDQUAL instrument proposed were adapted by using a theoretical framework of the scale called SERVQUAL and they were used to measure specific terms related to the department where this research was conducted ${ }^{6,7}$. A specific feature of this study lies in the fact that all those items which healthcare staff of individual departments cannot influence personally were excluded from the research. The structure and hence the analysis of the new instrument proposed differs from the SERVQUAL methodology because the original testing instrument is based on two identical parts of the questionnaire a service receiver has to fill out before (Expectations) and after (Perception) receiving a service. When applying MEDQUAL, the researchers use one questionnaire and start with the assumption that the expectations of a healthcare service are always highest (in case of a 5-point Likert scale, the expectations are measured by number 5$)^{8,26,27}$. Therefore, patients and medical staff were offered only one 23-item questionnaire, which measured the perception of the quality of the healthcare service provided/received. The items are related to the perception of $\mathrm{pa}^{-}$ tients/medical staff of the following: (1) building trust in the doctor-patient relationship; (2) professionalism of doctors while providing a healthcare service; (3) professionalism of nurses while providing a healthcare service; and (4) organization of the department. 


\section{Statistical analysis}

Categorical data were expressed as absolute and relative frequencies. Numerical data were described as the mean and standard deviation in the case of normal distribution, and in other cases as the median and limits of the interquartile range. Exploitation factor analysis was used to test the variable structure and dimensionality of the construct measured. Bartlett's test of sphericity and Kaiser-Meyer-Olkin (KMO) test were used for investigation of mutual correlation between manifest variables. The Kaiser-Rice criterion (1974) was used to interpret the KMO test, i.e. a value greater than or equal to 0.9 is marvelous, a value of at least 0.8 is meritorious, a value of 0.7 or more is middling, a value of 0.6 or more is mediocre, a value of 0.5 or more is said to be miserable, and a value less than 0.5 is considered unacceptable ${ }^{28}$. In factor rotation, the Varimax method was applied by using the Kaiser criterion.

We examined internal consistency by means of Cronbach's alpha reliability coefficient. To test the difference between the average individual MEDQUAL dimensions and the types of respondents that assessed the quality of medical services, the authors used the independent samples t-test or Mann-Whitney test, when appropriate. The normality of distribution was tested by Kolmogorov-Smirnov test. The level of significance was set at 0.05 . Data analysis was performed by using the IBM SPSS Statistics 23.0 statistical software.

\section{Results}

The study included 300 respondents. The sample consisted of 130 (43.3\%) male and 170 (56.7\%) female representatives (Table 1$)$.

More female representatives $\left(\chi^{2}=13.718, \mathrm{df}=1\right.$, $\mathrm{p}<0.001)$ were found in the group of medical service providers. The group of medical service recipients was on average slightly older ( 49.7 years) than the group of medical service providers (39.6 years).

The scale tested was composed of 25 items. After rotation (Varimax using the Kaiser criterion), items were distributed in 4 factors. Retained items (i.e. 23 items) with the highest loading factors are shown in Table 2. All correlations in the correlation matrix were above 0.5 , the value of Bartlett's test for statistical significance of the correlation matrix was $\chi^{2}=6833.86$ $(\mathrm{df}=253, \mathrm{p}<0.001)$. The KMO test result was 0.943 .

The total variance explained for MEDQCAL was $72.73 \%$ (Table 2). Factor 1, which has the highest value of explained variance of the scale presented, may be called 'Trust in the doctor' in the patient-medical staff relationship, and is characterized by variables related to building the doctor-patient relationship, which is the basis of every treatment. The second and third factors relate to medical staff professionalism, where the former consists of items related to nursing professionalism, and the latter to medical professionalism. Both factors are characterized by variables related to staff attitude towards their work, which contributes to fur-

Table 1. Research respondents

\begin{tabular}{|c|c|c|c|c|}
\hline & & $\begin{array}{l}\text { Medical service } \\
\text { recipients (patients), } \\
\mathrm{n}(\%)\end{array}$ & $\begin{array}{l}\text { Medical service } \\
\text { providers } \\
\text { (medical staff), } \mathrm{n}(\%)\end{array}$ & $\begin{array}{l}\text { Total } \\
\text { N (\%) }\end{array}$ \\
\hline $\begin{array}{l}\text { Gender } \\
\text { [n (\%)] }\end{array}$ & $\begin{array}{l}\text { Male } \\
\text { Female } \\
\text { Total }\end{array}$ & $\begin{array}{l}89(52.7) \\
80(47.3) \\
169(100.0)\end{array}$ & $\begin{array}{l}41(31.3) \\
90(68.7) \\
131(100.0)\end{array}$ & $\begin{array}{l}130(43.3) \\
170(56.7) \\
300(100.0)\end{array}$ \\
\hline Age & $\begin{array}{l}\mathrm{n} \\
\mathrm{M}(\mathrm{SD})\end{array}$ & $\begin{array}{l}169 \\
49.7(16.8)\end{array}$ & $\begin{array}{l}131 \\
39.6(10.3)\end{array}$ & 300 \\
\hline $\begin{array}{l}\text { Level of education } \\
{[\mathrm{n}(\%)]}\end{array}$ & $\begin{array}{l}\text { Elementary school } \\
\text { High school } \\
\text { Junior college } \\
\text { Bachelor's degree } \\
\text { Master's or PhD degree } \\
\text { Total }\end{array}$ & $\begin{array}{l}30(18.5) \\
93(57.4) \\
18(11.1) \\
18(11.1) \\
3(1.9) \\
162(100.0)\end{array}$ & $\begin{array}{l}81(62.3) \\
17(13.1) \\
28(21.5) \\
4(3.1) \\
130(100.0)\end{array}$ & $\begin{array}{l}30(10.3) \\
174(59.6) \\
35(12.0) \\
46(15.8) \\
7(2.4) \\
292(100.0)\end{array}$ \\
\hline
\end{tabular}


Table 2. Rotated component matrix (23 MEDQUAL items)

\begin{tabular}{|c|c|c|c|c|}
\hline & \multicolumn{4}{|c|}{ Component } \\
\hline & 1 & 2 & 3 & 4 \\
\hline $\begin{array}{l}\text { The doctor explained to the patient in an easy and understandable way } \\
\text { the procedures and interventions that need to be done. }\end{array}$ & 0.855 & & & \\
\hline The doctor informed the patient about the potential risks. & 0.854 & & & \\
\hline $\begin{array}{l}\text { The doctor explained to the patient his/her health condition in an easy } \\
\text { and understandable way. }\end{array}$ & 0.788 & & & \\
\hline The doctor responds to a patient's need for conversation and additional information. & 0.763 & & & \\
\hline A patient's right to privacy is ensured. & 0.550 & & & \\
\hline A patient has confidence in the doctor. & 0.527 & & & \\
\hline Nurses are compliant (willing to help). & & 0.812 & & \\
\hline Nurses kindly respond to a patient's call. & & 0.810 & & \\
\hline Nurses do their job professionally. & & 0.753 & & \\
\hline Patients have confidence in nurses. & & 0.706 & & \\
\hline Nurses look neat. & & 0.620 & & \\
\hline A surgical service has been performed professionally. & & & 0.783 & \\
\hline You felt safe during the performance of a surgical service. & & & 0.743 & \\
\hline Doctors are experts. & & & 0.673 & \\
\hline Doctors are compliant (willing to help). & & & 0.604 & \\
\hline Doctors take care of patients. & 0.516 & & 0.566 & \\
\hline Doctors are professional in regard to their relationship with patients. & & & 0.552 & \\
\hline Doctors look neat. & & & 0.517 & \\
\hline $\begin{array}{l}\text { A surgical service was provided at a time agreed upon in advance, } \\
\text { with no longer waiting period. }\end{array}$ & & & 0.517 & \\
\hline A surgical department is equipped with modern equipment. & & & & 0.737 \\
\hline The rooms for hospitalized patients are adequately equipped. & & & & 0.729 \\
\hline A surgical department is well equipped with medical supplies. & & & & 0.716 \\
\hline A surgical department is clean (tidy). & & & & 0.538 \\
\hline$\%$ of explained variance & 20.75 & 18.90 & 18.21 & 14.87 \\
\hline $\begin{array}{l}\text { Cumulative } \% \\
\text { of explained variance }\end{array}$ & 20.75 & 39.56 & 57.86 & 72.73 \\
\hline
\end{tabular}

ther strengthening of confidence and patient safety. The items associated with the organization and functioning of the department, as well as its equipment are grouped into the last, i.e. fourth factor called 'The organization of a department'.

Psychometric analysis of the entire MEDQUAL scale showed internal consistency since the standardized Cronbach's alpha was 0.961 . The inter-item correlation and item-total correlation were examined in the analysis of reliability. The value of the standardized Cronbach's alpha in certain dimensions of the MEDQUAL scale ranged from 0.810 to 0.938 (Appendix 1).
Differences in the assessment of healthcare service quality (the MEDQUAL scale and every single dimension of the MEDQUAL scale) assigned by patients and medical staff (Table 3), medical staff (Table 4) and patients (Table 5) were examined. In relation to medical staff, all patients $(\mathrm{p}<0.001)$ significantly better assessed the quality of the healthcare service received in all dimensions of the MEDQUAL scale and the entire MEDQUAL scale (Table 5).

For all dimensions of the MEDQUAL scale and the total MEDQUAL scale, patients evaluated the quality of services provided higher than medical staff. Doctors assigned a statistically significantly higher 
Table 3. Evaluation of the quality of the healthcare service provided/received in surgical department

\begin{tabular}{|c|c|c|c|c|c|c|c|}
\hline \multirow{2}{*}{\multicolumn{2}{|c|}{ MEDQUAL and dimensions }} & $\begin{array}{l}\text { Patients } \\
(\mathrm{n}=153)\end{array}$ & $\begin{array}{l}\text { Medical } \\
\text { staff }(n=131)\end{array}$ & \multirow{2}{*}{$\begin{array}{l}\text { Difference } \\
\text { between } \\
\text { medians }\end{array}$} & \multicolumn{2}{|c|}{$\begin{array}{l}\text { 95\% CI for } \\
\text { difference in } \\
\text { medians }\end{array}$} & \multirow[t]{2}{*}{$\mathrm{p}^{*}$} \\
\hline & & \multicolumn{2}{|l|}{ Median } & & Lower & Upper & \\
\hline \multicolumn{2}{|c|}{ MEDQUAL } & 4.54 & 3.87 & 0.65 & 0.41 & 0.89 & $<0.001$ \\
\hline \multicolumn{2}{|c|}{ Trust in the doctor } & 4.67 & 3.67 & 1.00 & 0.65 & 1.35 & $<0.001$ \\
\hline Professionalism & $\begin{array}{l}\text { Nurses } \\
\text { Medical (doctors) }\end{array}$ & $\begin{array}{l}4.80 \\
4.75\end{array}$ & $\begin{array}{l}4.00 \\
3.88\end{array}$ & $\begin{array}{l}0.80 \\
0.87\end{array}$ & $\begin{array}{l}0.52 \\
0.64\end{array}$ & $\begin{array}{l}1.08 \\
1.10\end{array}$ & $\begin{array}{l}<0.001 \\
<0.001\end{array}$ \\
\hline \multicolumn{2}{|c|}{ Organization of the department } & 4.25 & 3.50 & 0.75 & 0.47 & 1.03 & $<0.001$ \\
\hline
\end{tabular}

*Mann-Whitney test; 95\% CI = 95\% confidence interval

Table 4. Assessment of the quality of the healthcare service provided by surgical department

\begin{tabular}{|c|c|c|c|c|c|c|c|}
\hline \multirow{2}{*}{\multicolumn{2}{|c|}{ MEDQUAL and dimensions }} & $\begin{array}{l}\begin{array}{l}\text { Nurses } \\
(\mathrm{n}=101)\end{array} \\
\end{array}$ & \begin{tabular}{|l} 
Doctors \\
$(\mathrm{n}=30)$
\end{tabular} & \multirow{2}{*}{$\begin{array}{l}\text { Mean } \\
\text { difference }\end{array}$} & \multicolumn{2}{|c|}{$95 \% \mathrm{CI}$ of difference } & \multirow[t]{2}{*}{$\mathrm{p}^{*}$} \\
\hline & & \multicolumn{2}{|c|}{ Mean (SD) } & & Lower & Upper & \\
\hline \multicolumn{2}{|c|}{ MEDQUAL } & $3.78(0.70)$ & $3.94(0.68)$ & -0.159 & -0.45 & 0.13 & 0.275 \\
\hline \multicolumn{2}{|c|}{ Trust in the doctor } & $3.62(0.88)$ & $3.75(0.91)$ & -0.129 & -0.49 & 0.24 & 0.485 \\
\hline \multirow{2}{*}{ Professionalism } & Nurses & $4.00(0.74)$ & $3.94(0.86)$ & 0.062 & -0.25 & 0.38 & 0.697 \\
\hline & Medical (doctors) & $3.90(0.75)$ & $4.24(0.60)$ & -0.136 & -0.63 & -0.04 & 0.029 \\
\hline \multicolumn{2}{|c|}{ Organization of the department } & $3.51(0.81)$ & $3.64(0.92)$ & -0.332 & -0.48 & 0.21 & 0.436 \\
\hline
\end{tabular}

*Independent samples t-test; 95\% CI = 95\% confidence interval

Table 5. Assessment of the quality of the received healthcare service provided by surgical department according to the type of patients

\begin{tabular}{|c|c|c|c|c|c|c|c|}
\hline \multirow{2}{*}{\multicolumn{2}{|c|}{ MEDQUAL and dimensions }} & $\begin{array}{l}\text { Outpatient } \\
(\mathrm{n}=78)\end{array}$ & $\begin{array}{l}\text { Inpatient } \\
(\mathrm{n}=76)\end{array}$ & \multirow{2}{*}{$\begin{array}{l}\text { Difference } \\
\text { between } \\
\text { medians }\end{array}$} & \multicolumn{2}{|c|}{$\begin{array}{l}95 \% \text { CI for } \\
\text { difference in } \\
\text { medians }\end{array}$} & \multirow[t]{2}{*}{$\mathrm{p}^{*}$} \\
\hline & & \multicolumn{2}{|l|}{ Median } & & Lower & Upper & \\
\hline \multicolumn{2}{|l|}{ MEDQUAL } & 4.48 & 4.66 & -0.18 & -0.46 & 0.11 & 0.067 \\
\hline \multicolumn{2}{|c|}{ Trust in the doctor } & 4.64 & 4.67 & -0.04 & -0.44 & 0.37 & 0.566 \\
\hline Professionalism & $\begin{array}{l}\text { Nurses } \\
\text { Medical (doctors) }\end{array}$ & $\begin{array}{l}4.60 \\
4.67\end{array}$ & $\begin{array}{l}5.00 \\
4.83\end{array}$ & $\begin{array}{l}-0.40 \\
-0.16\end{array}$ & $\begin{array}{l}-0.73 \\
-0.42\end{array}$ & $\begin{array}{l}-0.07 \\
0.10\end{array}$ & $\begin{array}{l}0.048 \\
0.210\end{array}$ \\
\hline \multicolumn{2}{|c|}{ Organization of the department } & 4.25 & 4.50 & -0.25 & -0.62 & 0.12 & 0.028 \\
\hline
\end{tabular}

*Mann-Whitney test; 95\% CI = 95\% confidence interval

mean rating (4.24) to the dimension of professionalism than nurses (3.90) (Table 4).

Finally, in the analysis of satisfaction with the quality of medical services, there was no statistically significant difference in any dimension with regard to the type of patients (i.e. inpatient or outpatient). Since there were no statistically significant differences, it was confirmed that the same standards were used in taking care of all types of patients.

\section{Discussion}

Several papers have been published regarding measurement of the quality of medical services so far, but 
none of them simultaneously tested two groups, i.e. four subgroups of respondents who participate in the process of receiving/providing healthcare services ${ }^{9-23}$. In this study, the MEDQUAL scale was designed and tested. The authors aimed to construct a questionnaire that would collect data easily, be applicable to all participants involved in the process of both receiving and providing healthcare services and to all hospital departments, and be adaptable to future trends in hospital practice.

MEDQUAL items examine personal and collective contribution of medical staff to the quality of healthcare provided in a particular department. The MEDQUAL scale was designed to avoid the impact of external, i.e. paramedical factors on final assessment of the quality of healthcare services. Differences in the attitudes of two groups of medical staff (doctors and nurses) and the divergent views of medical staff and patients, as well as differences between outpatients and inpatients on the provided/received healthcare service were analyzed.

The characteristics of this scale in terms of its application in assessing the quality of a healthcare service provided/received in one or all departments in hospitals are as follows: repeatable, cost-effective, reliable, time-saving (examines only perception), interpretable and comparable. In this study, comparability as a positive feature of the MEDQUAL scale refers to the comparability of its results by groups of subjects, departments, institutions and time.

Analysis of results shown in Tables 4 and 5 shows that the lowest ratings in all groups of respondents were assigned to the organization of the department, on which medical staff had the least direct impact, whereas professionalism of medical staff obtained the highest scores in all examined groups. In the 'trust in the doctor' dimension, a lower score could be attributed to the lack of time that doctors devote to their patients to the extent which both the patient and medical staff consider necessary. Given the shortage of medical staff and the fact that they are overburdened, particularly with administrative tasks, such result is not unexpected. Further improvements in the quality of medical services could be achieved by reallocating tasks to the existing administration following appropriate training, better computerization and connection of the health information system that would allow easier and faster access to relevant information and enable doctors and nurses to have more time for patients.

\section{Conclusion}

Medical institutions are providers of healthcare services, which are specific in all their segments, particularly when it comes to their impact on the health and life of the service recipient. As quality measurement of the majority of the services that are provided can be developed methodologically, the quality of the medical service provided is also a multidimensional measurable construct. By measuring service quality, a system of indicators has been established to determine those dimensions of the service that require analysis and training in a particular healthcare system. In this study, measurement of the quality of healthcare services was based on the existing theoretical and applicable knowledge of measuring concepts of the service phenomenon that had already been developed. Since SERVQUAL as one of these concepts has experienced numerous adaptations in various service activities, it has been adapted to MEDQUAL in the field of medical services, analyzed and critically commented. The MEDQUAL scale has certain drawbacks. The first is its low specificity. This deficiency can be resolved by adding items that are specific for a certain area or group of patients (e.g., pediatrics, psychiatry). Ongoing research of the MEDQUAL scale could further be adapted and applied to specific groups (PEDQUAL, PSYCHOQUAL), or to the institution as a whole and in order to detect additional factors that affect the quality of healthcare service (HOSPIQUAL). The second drawback of the results presented is that testing was made only in one hospital department. The third disadvantage can be found in the need to collect data in waves (i.e. equal time intervals), which is organizationally demanding. The findings of this study provide a simultaneous assessment of the quality of healthcare services provided/received in one department with the possibility of a longitudinal study of this phenomenon. In order to make further progress in improving the quality of healthcare services, it is essential to engage department managers/stakeholders and to sustain interest in and the need for cooperation with medical staff, which could result in better organization of departments and better equipment, and more time for patients, which will eventually result in higher patient and medical staff satisfaction, and ultimately, increased satisfaction with the healthcare service provided/received. 


\section{Appendix 1 \\ Review of internal consistency of each dimension of the MEDQUAL scale and total MEDQUAL scale}

\begin{tabular}{|l|l|l|l|l|l|}
\hline Dimension & MEDQUAL & 1 & 2 & 3 & 4 \\
\hline Number of items & 23 & 6 & 5 & 8 & 4 \\
Cronbach's alpha & 0.961 & 0.922 & 0.911 & 0.933 & 0.808 \\
Standardized Cronbach's alpha & 0.964 & 0.923 & 0.913 & 0.938 & 0.810 \\
Mean item value & 4.080 & 3.906 & 4.144 & 4.233 & 3.863 \\
Mean inter-item correlation & 0.537 & 0.668 & 0.667 & 0.654 & 0.516 \\
Mean item-total correlation & 0.718 & 0.781 & 0.780 & 0.778 & 0.631 \\
\hline
\end{tabular}

\section{References}

1. Grönroos C. A service quality model and its marketing implications. Eur J Mark. 1984;18(4):36-44, https://doi.org/10.1108/EUM0000000004784

2. Parasuraman A, Zeithaml V, Berry LL. A conceptual model of service quality and its implications for future research. J Mark. 1985;49(Fall):41-50, doi: 10.2307/1251430

3. Haywood-Farmer J. A conceptual model of service quality. Int J Oper Prod Manag. 1988;8(6):19-29, https://doi.org/10.1108/eb054839

4. Parasuraman A, Zeithaml V, Berry LL. SERVQUAL: a multiple item scale for measuring consumer perceptions of service quality. J Retailing. 1988;64(1):12-40.

5. Parasuraman A, Zeithaml V, Berry LL. Refinement and reassessment of the SERVQUAL scale. J Retailing. 1991;67(4): 420-50.

6. Parasuraman A, Zeithaml V, Berry LL. Research note: more on improving service quality measurement. J Retailing. 1993;69 (1):140-7.

7. Parasuraman A, Zeithaml V, Berry LL. Reassessment of expectations as a comparison standard in measuring service quality: implications for future research. J Mark. 1994;58:111-24, DOI: $10.2307 / 1252255$

8. Buttle F. SERVQUAL: review, critique, research agenda. Eur J Mark. 1996;30(1):8-31, https://doi.org/10.1108/03090569610105762

9. Reidenbach ER, Sandifer-Smallwood B. Exploring perceptions of hospital operations by a modified SERVQUAL approach. J Health Care Mark. 1990;10(4):47-55.

10. Babakus E, Mangold GW. Adapting the SERVQUAL scale to hospital services: an empirical investigation. Health Sev Res. 1992;26(6):767-86.

11. Andaleeb SS. Service quality perceptions and patient satisfaction: a study of hospitals in developing country. Soc Sci Med. 2001;52:1359-70, https://doi.org/10.1016/S0277-9536(00)00235-5
12. Andaleeb SS. Public and private hospitals in Bangladesh: service quality and predictors of hospital choice. Health Policy Plann. 2000;15(1):95-102, https://doi.org/10.1093/heapol/15.1.95

13. Tilney MK. Clinical quality improvement and medicine. Eur J Intern Med. 2004;15:487-95, https://doi.org/10.1016/j.ejim.2004.09.001

14. Lee MA, Yom YH. A comparative study of patients' and nurses' perceptions of the quality of nursing services, satisfaction and intent to revisit the hospital: a questionnaire survey. Int Nurs Stud. 2007;44:545-55, https://doi.org/10.1016/j.ijnurstu.2006.03.006

15. McCarthy ML, Ding R, Zeger SL, et al. A randomized controlled trial of the effect of service delivery information on $\mathrm{pa}^{-}$ tient satisfaction in an Emergency Department Fast Track. Acad Emerg Med. 2011;18:674-85, https://doi.org/10.1111/j.1553-2712.2011.01119.x

16. Szyca R, Rosiek A, Nowakowska U, et al. Analysis of factors influencing patient satisfaction with hospital treatment at the surgical department. Pol Przegl Chir. 2012;84(3):136-43, https://doi.org/10.2478/v10035-012-0022-3

17. Piligrimienė $\check{Z}$. Measurement issues in health care service quality. Econ Manag. 2012;17(1):289-96, http://dx.doi.org/10.5755/j01.em.17.1.2280

18. Senić V, Marinković V. Patient care, satisfaction and service quality in health care. Int J Consum Stud. 2012;37(2):1-7, https://doi.org/10.1111/j.1470-6431.2012.01132.x

19. Šklebar I, Mustajbegović J, Šklebar D, Cesarik M, Milošević $\mathrm{M}$, Brborović $\mathrm{H}$, et al. How to improve patient safety culture in Croatian hospitals? Acta Clin Croat. 2016;55(3):370-80, https://doi.org/10.20471/acc.2016.55.03.04

20. Guiry M, Vequist D. Traveling abroad for medical care: U.S. medical tourists expectations and perceptions of service quality. Health Mark Q. 2011;28:253-69, https://doi.org/10.1080/07359683.2011.595644

21. Vrkljan S, Hendija Z. Business performance of health tourism service providers in the Republic of Croatia. Acta Clin Croat. 2016;55(1):79-86, doi: 10.20471/acc.2016.55.01.12 
22. Zineldin M, Camgöz-Akdağ H, Vasicheva V. Measuring, evaluating and improving hospital quality parameters/dimensions - an integrated healthcare quality approach. Int J Health Care Qual. Assur. 2011;24(8):654-62, https://doi.org/10.1108/09526861111174215

23. Dagger TS, Sweeney JC, Johnson LW. A hierarchical model of health service quality: scale development and investigation of integrated model. J Serv Res. 2007;10(2):123-42, https://doi.org/10.1177/1094670507309594

24. Hair J, Black W, Babin B, et al. Multivariate Data Analysis. Upper Saddle River, NJ: Pearson Prentice Hall, 2010; p. 102.

25. Nunnally J. Psychometric Methods. New York: McGraw-Hill, 1978; p. 276.
26. Cronin JJ, Taylor SA. SERVPERF versus SERVQUAL: reconciling performance-based and perceptions-minus-expectations measurement of service quality. J Mark. 1994;58(1):125-31, doi: $10.2307 / 1252256$

27. Francois AC, Fernando J, Jay PM. The validity of the SERVQUAL and SERVPERF scales: a meta-analytic view of 17 years of research across five continents. Int J Serv Industry Manag. 2007;18(5):472-90, https://doi.org/10.1108/09564230710826250

28. Kaiser HF, Rice J. Little Jiffy, Mark Iv. Educ Psychol Meas. 1974: 34(1): 111-7, https://doi.org/10.1177/001316447403400115

Sažetak

\title{
MJERENJE KVALITETE ZDRAVSTVENE SKRBI - PARADIGMA MEDQUAL
}

\author{
K. Musa-Juroš, J. Mijoč, J. Horvat, V. Ilakovac, S. Marković i A. Racz
}

Polazišna pretpostavka rada bila je da je medicinska djelatnost uslužna djelatnost učinke koje je moguće mjeriti kao i u drugim uslužnim djelatnostima. Istraživanjem izgrađenih i testiranih mjernih instrumenata za ocjenu kvalitete uslužnih djelatnosti izabran je mjerni instrument SERQUAL te je adaptiran u MEDQUAL. Mjerni instrument MEDQUAL ima za cilj mjerenje kvalitete pojedinačne medicinske usluge odnosno kvalitete medicinske usluge medicinskog osoblja jednog bolničkog odjela umjesto kvalitete cjelokupne bolničke usluge ili dijelova usluge na koje osoblje ne može utjecati, jer je ranije određeno drugim čimbenicima. Istraživanje je provedeno na jednom odjelu klinike u Republici Hrvatskoj u kojem je sudjelovalo 300 ispitanika (169 bolesnika i 131 član medicinskog osoblja). Istraživanjem je izrađen i testiran mjerni instrument MEDQUAL visoke pouzdanosti na svim utvrđenim dimenzijama: povjerenje u liječnika (C. alfa 0,923), profesionalnost medicinskih sestara $(0,913)$, profesionalnost liječnika $(0,938)$ te organizacija klinike $(0,810)$. Temeljna odlika predloženog mjernog instrumenta ogleda se u mogućnosti istodobne ocjene zadovoljstva kvalitetom pružene i primljene medicinske usluge rezultata usporedivih prema skupinama ispitanika, odjelima, ustanovama s potencijalom longitudinalnog praćenja ovog fenomena. MEDQUAL je jednostavan, primjenjiv na sve odjele, učinkovit i ponovljiv mjerni instrument za mjerenje kvalitete pružene/primljene medicinske usluge, koji ima svoje mjesto u procjeni kvalitete medicinske usluge kao i u njenom poboljšanju.

Ključne riječi: Kvaliteta zdravstvene skrbi; medicinsko osoblje; bolnički odjeli; Hrvatska; zadovoljstvo bolesnika; ankete i upitnici; longitudinalne studije; pokazatelji kvalitete zdravstvene skrbi 